Foro, Nueva época, vol. 16, núm. 2 (2013): 231-257

ISSN:1698-5583

http://dx.doi.org/10.5209/rev_FORO.2013.v16.n2.43938

\title{
LA PROPIEDAD PRIVADA Y SU ÍNDOLE ELÁSTICA
}

\author{
Vidal Rivera Sabatés \\ Departamento de Derecho Civil \\ Universidad Complutense de Madrid \\ vrivera@der.ucm.es
}

\begin{abstract}
RESUMEN
La propiedad, el derecho real por excelencia, es el más amplio poder de dominación que el ordenamiento jurídico permite asumir sobre un bien. Análisis de la definición legal plasmada en el art. 348 del Código Civil y comentario de las críticas, tanto técnicas como político-sociales, que ha recibido la misma. Significado y alcance de uno de los caracteres esenciales del dominio: su elasticidad o fuerza expansiva.
\end{abstract}

Palabras clave: propiedad, dominio, ius in re aliena, facultades dominicales, elasticidad.

\section{ABSTRACT}

Possession, real property right par excellence, is the greatest dominating power that the legal system allows us to take on a certain good. Analysis of the legal definition captured in article 348 of the Civil Code and reviews comments, as much technical as social/ political, which the latter has arisen. Meaning and scope of one of the main features of possession: its elasticity or spreading power.

Keywords: property, possession, ius in re aliena, possession rights, elasticity.

\section{ZUSAMMENFASSUNG}

Das Privateigentum, das Sachrecht par excelence, ist die weitreichendste Herrschaftsausübung, die die Rechtsordnung über ein Gut gestattet. Der vorliegende Artikel analysiert die Rechtsdefinition, wie sie im Art. 348 des Spanischen Bürgerlichen Gesetzbuchs abgebildet ist. Zugleich kommentiert er die Kritiken - seien sie technischer oder politisch-sozialer Natur -, die diese Rechtsdefinition erfahren hat. Ferner werden die Bedeutung und Tragweite der beiden entscheidenden Wesensmerkmale des Besitzanspruches analysiert: seine Elastizität und seine expansive Kraft.

Schlüsselwörter: Eigentum, Besitz, ius in re aliena, Eigentumsrecht, Elastizität. 
La propiedad, verdadera ley de la gravitación moral ${ }^{1}$, se destaca como una figura primordial en la vida humana (una de las piedras angulares de nuestra civilización ${ }^{2}$, donde cada dueño - como postula Fabié- ${ }^{3}$ funge de «soldado del orden»), en la medida en que patentiza el vínculo íntimo que constantemente y de manera imprescindible mantiene el hombre con la naturaleza ${ }^{4}$ a fin de lograr de ella, mediante la cabal aplicación de su actividad - trabajo-, los rendimientos, aprovechamientos y utilidades de que es susceptible ${ }^{5}$. Tal propiedad, en cuanto hecho, supone una relación económica - la relación económica por antonomasia- y entraña como relación humana, en opinión de un perspicuo Manresa y Navarro ${ }^{6}$, un sistema o conjunto de condiciones cuya ordenación adecuada constituye el derecho especial (derecho de propiedad) de esa relación ${ }^{7}$.

${ }^{1}$ La refulgente expresión es del conspicuo jurisconsulto y político Alonso Martínez, para quien, si se suprime la propiedad, desaparecerán las clases, «es decir, que no habrá montañas, ni valles, ni capas sociales colocadas en el orden de sus densidades, ninguna superioridad legítima, ningún orden jerárquico; pero cabalmente por esto quedará descoyuntado el organismo social, y a la actividad intelectual e industrial sucederá la pereza, y al progreso, la ignorancia, y a la prosperidad la miseria, y no se podrán formar por la acumulación de las economías, capitales para promover el aumento de nueva riqueza; y sin el aguijón de la concurrencia, del interés personal [...] cesará la lucha fecunda del trabajo, de la libertad individual y del respeto a sus creaciones; y esta vida social, tan agitada y rica en accidentes, merced a los cuales el hombre mejora gradualmente de condición y desenvuelve todas sus facultades, se tornará al principio en la vida uniforme y monótona de un ingenio cultivado por esclavos». Cfr. Manuel Alonso Martínez, «Estudios sobre el derecho de propiedad», en Carlos Rogel y Carlos VatTier (coords.), Manuel Alonso Martínez. Vida y obra, Madrid, Tecnos-Caja de Ahorros Municipal de Burgos, 1991, p. 978.

2 Cfr. Henri De Page, Traité élémentaire de droit civil belge, t. V, avec la collaboration, pour la partie relative aux biens, de René DEKKERS, nouveau tirage conforme au premier, Bruxelles, Établissements Émile Bruylant, 1952, $\$$ 894, p. 784. Véase también Federico PuIG PeÑA, Tratado de Derecho civil español, t. III, vol. I, Madrid, Edersa, s.f., p. 55.

${ }^{3}$ En un discurso pronunciado en el Senado, Diario de Sesiones, núm. 68, de 21 de febrero de 1885, recogido en El Código Civil. Debates parlamentarios (1885-1889), t. I, estudio preliminar de José Luis DE LOS Mozos, edición preparada por Rosario HeRRERO GuTIÉRREZ y María Ángeles VALLejo ÚBEDA, Madrid, Servicio de Publicaciones de la Secretaría General del Senado, 1989, p. [57].

${ }^{4}$ Véase Felipe Sánchez Román, Estudios de Derecho civil, t. III, Madrid, Est. Tip. Sucesores de Rivadeneyra, 1900, p. 31.

${ }^{5}$ El núcleo central de la propiedad es un monopolio del señorío de percibir los rendimientos económicos de una cosa. Cfr. Luis Dítz-PicAzo, «Propiedad y Constitución», en VVAA, Propiedad y Derecho civil, Madrid, Colegio de Registradores de la Propiedad y Mercantiles de España, 2006, p. 14.

${ }^{6}$ José María Manresa y Navarro, Comentarios al Código Civil español, t. III, 7. a ed. revisada y puesta al día por José Calvillo Martínez de Arenaza, Madrid, Reus, 1952, p. 174.

7 Derecho de propiedad — concretará De Diego - es «el poder legítimo (sancionado y disciplinado por el Derecho) de actuar la relación del hombre con la naturaleza para 
Como reacción frente a las tradicionales definiciones del derecho de propiedad o dominio $^{8}$ (términos manejados en lo sucesivo como sinónimos $^{9}$, adhiriéndome al meridiano verbo empleado, por ejemplo, por los arts. 669.1 del Código Civil colombiano ${ }^{10}$ o 582.1 del chileno ${ }^{11}$ ), cuya más famosa muestra era la que lo caracterizaba como «ius utendi et abutendi re sua quatenus iuris ratio patitur: unusquisque enim est rerum suarum moderator et arbiter, nisi lex arbitrium tollat ${ }^{12}$ —acompañada de otras solu-

el aprovechamiento de las cosas en la satisfacción de las humanas necesidades». Cfr. Felipe Clemente De Diego, Instituciones de Derecho civil español, Madrid, Imprenta de Juan Pueyo, 1929, p. 301.

${ }_{8}$ Sobre este punto es de reseñar el lúcido parecer del señor De Azcárate: «La propiedad se toma en dos sentidos: uno genérico y otro específico. Según aquél, abarca todo género de relaciones referentes a los bienes económicos, y por lo mismo comprende así el estricto derecho de propiedad como el de obligaciones, pudiendo ser la cosa propia un predio, un crédito o una letra de cambio; en una palabra, todo lo que constituye el haber o patrimonio de una persona. Conforme al segundo, abraza tan sólo las relaciones referentes a un objeto sometido de una manera más o menos absoluta y exclusiva a nuestro poder, y en tal caso se considera como equivalente a dominio». Cfr. Gumersindo DE AzCÁRATE, Ensayo sobre la historia del derecho de propiedad y su estado actual en Europa, t. III, Madrid, Imprenta de la Revista de Legislación, 1883, pp. 25 y 26. Véanse igualmente José María MANRESA y NAVARRO, Comentarios al Código Civil español, op. cit., p. 184; Diego EsPín Cánovas, Manual de Derecho civil español, vol. II, 3. . ed. revisada y puesta al día, Madrid, Edersa, 1968, p. 67, y Federico Puig PeÑa, Tratado de Derecho civil español, op. cit., pp. 55 y 56.

9 Así los emplean también nuestra ley (véanse los arts. 338 y ss., 348 a 350, 407 y ss., $432,605,606,608,1.940$ y ss., etc.), jurisprudencia y doctrina. Aunque - como sintetiza Manuel Albaladejo García, Derecho civil, t. III, 11. a ed. revisada por Encarna Cordero Lobato, Madrid, Edisofer, 2010, p. 231- al iniciar el estudio de esta materia algunos autores planteen ciertas diferencias entre ambos vocablos, «lo cierto es que, después (como no podría ser menos ante la objetividad de las cosas), manejan ambos indistintamente». Cfr. también Leopoldo Alas ArgüElles, Derecho civil, Madrid, Reus, 1929, pp. 246 y 247; Demófilo DE BuEn, Derecho civil español común, vol. I, 2. ${ }^{a}$ ed., Madrid, Reus, 1931, p. 159, nota 1; Q. Mucius SCaevola, Código Civil comentado y concordado extensamente, t. VI, totalmente revisado y puesto al día por Francisco OrTEGA LORCA, 5. ${ }^{a}$ ed., Madrid, Instituto Editorial Reus, 1949, pp. 451 y 452; José Luis De Los Mozos, El derecho de propiedad: crisis y retorno a la tradición jurídica, Madrid, Edersa, 1993, p. 3, y Eduardo SERRANo AlonSo y Eduardo SerRAno Gómez, Manual de derechos reales, 2. ${ }^{a}$ ed. revisada y puesta al día, Madrid, Edisofer, 2008, p. 79.

${ }^{10}$ «El dominio (que se llama también propiedad) es el derecho real en una cosa corporal, para gozar y disponer de ella arbitrariamente, no siendo contra ley o contra derecho ajeno».

${ }^{11}$ Salvo un signo ortográfico (un punto y coma en lugar de una simple coma), misma redacción que su homólogo colombiano.

${ }^{12}$ En las fuentes no se halla ninguna definición de la propiedad, dado que los jurisconsultos romanos no se preocupaban en demasía de las definiciones. La célebre definición latina reproducida, de acuerdo con las recientes investigaciones en la materia, no es anterior al siglo Xv. En esa definición, abuti tiene el significado de «consumir» (cfr. Dig., $5,3,25,11)$ y no el de «abusar», como se pretendía dar a entender. Cfr. también Dig., 1, 5, 4pr., y Codex, 4, 35, 21. Véanse Florencio García Goyena, Concordancias, moti- 
ciones más descriptivas aún que hacían prolija referencia, debidamente engarzados, al ius utendi, fruendi, possidendi, disponendi ${ }^{13}$, abutendi et vindicandi $i^{14}$ - , se ha defendido modernamente otro concepto inspirado en la también provecta fórmula de la plena in re potestas ${ }^{15}$ (entresacada de las Instituciones de Justiniano, libro II, título IV, $\$ 4^{16}$ ). Se censura hogaño con acritud ese tipo de definiciones enumerativas — de gusto cuantitativo- de la propiedad ${ }^{17}$ (que se detenían en las facultades que la integran

vos y comentarios del Código Civil español, t. I, Madrid, Imprenta de la Sociedad Tipográfico-Editorial, 1852, p. 352; François LAUREnt, Principes de Droit civil français, t VI, ParisBruxelles, A. Durand\&Pedone Lauriel/Bruylant-Christophe\&Comp., 1871, p. 135; Teófilo EsCRIBANO, «La propiedad y el art. 348 del Código Civil español», RDP, año IV, núm. 30, 15 de marzo de 1916, pp. 64 y 65; Biagio BrugI, Della proprietà, vol. I, ristampa della 2. ${ }^{a}$ edizione intieramente rifatta e corredata di indice alfabetico, Napoli-Torino, Eugenio Marghieri-Utet, 1923, pp. 11-12; Salvatore DI MARzo, Le basi romanistiche del Codice Civile, Torino, Utet, 1950, pp. 158-159; José María Manresa y Navarro, Comentarios al Código Civil español, op. cit., p. 186; Bartolomeo Dusi, Istituzioni di diritto civile, vol. I, rivedute ed aggiornate dal Magali SARfatti, 2. ${ }^{a}$ ed., Torino, Libreria Scientifica Giappichelli, 1945, p. 328, nota 1; Ferdinando PICCINELLI, Studi e ricerche intorno alla definizione dominium est ius utendi et abutendi re sua, quatenus iuris ratio patitur (rist. anast. 1886), con una nota di lettura di Luigi Capogrossi Colognesi, Napoli, Jovene (Collana Antiqua), 1980; Vicente L. Montés Penadés, Comentarios al Código Civil, dirigido por Manuel AlbalaDEJO, t. V, vol. I, 2. a ed. totalmente reelaborada y adaptada a la nueva legislación, Madrid, Edersa, 1990, p. 150, nota 5, y Josep M. a FARRÉ Alemán, Código Civil comentado y concordado, 1. ${ }^{a}$ ed., Barcelona, Bosch, enero de 2001, p. 413.

13 Para Bártolo de Sassoferrato: «Dominium est ius de re corporali perfecte disponendi nisi lege prohibeatur». Cfr. BARTOLO, Opera omnia, t. V, Venezia, 1615, fol. 84, ad l. 17, $\mathbb{1}$, D., 41, 2. Como indica Pietro Bonfante, Corso di diritto romano, vol. II, parte I, ristampa corretta della 1. ${ }^{a}$ edizione a cura di Giuliano Bonfante e di Giuliano CRIFÒ con l'aggiunta degli indici delle fonti, Milano, Giuffrè, 1966, p. 234, es el tipo de definición más simple y popular, tanto que se ha perpetuado y es la más difundida en los Códigos Civiles. Véase igualmente Biagio BRUGI, Della proprietà, op. cit., pp. 25-26.

${ }^{14} \mathrm{O}$, más brevemente, como el derecho de usar y disponer de la cosa (en cuanto en el uso se repute contenido el uti, frui, abuti; en la disposición, cualquier acto de enajenación, y en ambos, la protección legal de la reivindicatio). Véase Roberto DE RUGGIERO, Instituciones de Derecho Civil, vol. I, traducción de la $4 .{ }^{a}$ ed. italiana anotada y concordada con la legislación española por Ramón SERRANo SúÑER y José SANTA-CRuZ TeIJEIRO, Madrid, Reus, 1929, p. 523. Véase también el fundamento jurídico segundo de la STS de 1 de marzo de 1994 [RJ 1994/1633].

${ }_{15}$ Véase, al respecto, Ramón María RoCa SASTRE, «La concepción del usufructo como pars dominii y sus reflejos en la legislación del impuesto de derechos reales», RGLJ, año LXXXVII, núm. 6, segunda época, tomo IV (172 de la colección), diciembre de 1942, p. 583.

16 «Cum autem finitus fuerit totus ususfructus, revertitur ad proprietatem, et ex eo tempore nudx proprietatis dominus incipit plenam in re habere potestatem» $[=$ «Cuando el usufructo se extingue en (su) totalidad, se reúne con la propiedad, y el mero propietario tiene desde aquel momento un pleno poder sobre la cosa»]. Cfr. Instituciones de Justiniano, edición bilingüe con una nota previa sobre Justiniano y las Institutas por M. OrTOLÁn, traducción de Francisco Pérez de Anaya y Melquiades Pérez Rivas, Buenos Aires, Heliasta, s.f., p. 103.

${ }_{17}$ Cfr. José Castán TobeÑas, Derecho civil español, común y foral, t. II, vol. I, 14. ${ }^{a}$ ed. 
y las limitaciones que atenazan al titular), toda vez que se estima más idóneo retratarla como el más amplio ${ }^{18}$ (o alto ${ }^{19}$ o vasto ${ }^{20}$ ) derecho de señorío que puede ostentarse sobre una $\operatorname{cosa}^{21}$, el más extenso ${ }^{22}$ (o completo ${ }^{23} \mathrm{o}$ fuerte ${ }^{24}$ ) poder de dominación que sobre un bien permite el ordenamiento jurídico. No resulta de recibo — sostendrá Windscheid— ${ }^{25}$ propugnar que la propiedad consta de una suma o reunión de singulares facultades; consiste más bien en la plenitud del derecho sobre una $\operatorname{cosa}^{26}$, y tales facultades no representan sino simples exteriorizaciones o manifestaciones de dicha plenitud ${ }^{27}$. Expresado de otra forma, no es acertado querer enunciar todo lo que el dueño puede hacer (vana empresa ésta por inacabable, una suerte de tonel de las danaides que llenar), sino sólo lo que le está vedado, ya le venga impuesto el límite por la norma jurídica, ya derive de la concu-

revisada y puesta al día por Gabriel GarCÍA CANTERo, Madrid, Reus, 1992, p. 157. Véase también José Antonio MarTín Pérez, Comentarios al Código Civil, dirigido por Andrés Domínguez Luelmo, 1. a ed., Valladolid, Lex Nova, mayo de 2010, p. 477.

18 Véase Lodovico Barassi, La proprietà nel nuovo Codice Civile, 2. ${ }^{a}$ ed., Milano, Giuffrè, 1943, 1 1, núm. 1, p. 2, y Pietro ResCIGNO, voz «proprietà (diritto privato)», Enciclopedia del Diritto, vol. XXXVII, Milano, Giuffrè, 1988, p. 295. Cfr. también Xavier O'Callaghan Muñoz, Código Civil comentado y con jurisprudencia, 5. a ed., Madrid, La Ley, septiembre de 2006, p. 393. Cfr. también el fundamento jurídico tercero de la STS de 7 de octubre de 2005 [RJ 2005/6919].

${ }_{19}$ Cfr. Felipe Clemente DE DIEgo, Instituciones de Derecho civil español, op. cit., p. 314.

${ }^{20}$ Cfr. Pietro Bonfante, Corso di diritto romano, op. cit., p. 235.

${ }^{21}$ Véase Martin WolfF, Derecho de cosas, en Ludwig EnNECCERus, Theodor Kipp y Martin WolfF, Tratado de Derecho civil, t. III, décima revisión por Martin WolfF y Ludwig RaISER, traducción española con anotaciones de Blas Pérez GonzÁlez y José Alguer, vol. I, 3. ${ }^{a}$ ed. al cuidado de José Puig Brutau, Barcelona, Bosch, 1971, $\mathbb{\$} 51$, p. 326.

${ }^{22}$ Cfr. Juan Santamaría, Comentarios al Código Civil, t. I, Madrid, 1958, p. 388. Véase también Antoni M. Borrell i Soler, El dominio según el Código Civil español, Barcelona, Bosch, 1948, p. 55.

${ }^{23}$ Cfr. Leopoldo Alas ArgüElles, Derecho civil, op. cit., p. 238. Véase también Marcel Planiol y Georges RiPERT, Tratado práctico de Derecho civil francés, traducción española de Mario Díaz Cruz, t. III, con el concurso de M. Picard, La Habana, Juan Buxó, 1930, p. 204.

${ }^{24}$ Cfr. Antonio HeRnÁNDEZ GIL, «La propiedad y su transformación», Obras Completas, t. IV, Madrid, Espasa-Calpe, 1989, p. 45.

${ }_{25}$ Bernardo WinSDCHEID, Diritto delle pandette, traduzione dei professori Carlo Fadda e Paolo Emilio Bensa, con note e riferimenti al Diritto civile italiano, nuova ristampa stereotipa, vol. I, Torino, Utet, 1925, $\$ 167$, p. 591.

${ }^{26}$ El art. 832 del Código Civil italiano de 1942 estatuye que: «Il proprietario ba il diritto di godere e disporre delle cose in modo pieno ed esclusivo, entro i limiti e con l'osservanza degli obblighi stabiliti dall'ordinamento giuridico».

${ }_{27}$ Todas las posibles facultades jurídicas sobre la cosa están concentradas en la propiedad, no como derechos distintos, sino como pertenencias de la misma propiedad. Cfr. Bartolomeo Dusi, Istituzioni di diritto civile, op. cit., p. 329. Cfr. también Karl WirTH, Beiträge zur Systematik des römischen Civilrechts insbesondere binsichtlich obligatorischer und dinglicher Rechte, Erlangen, Verlag von A. Deichert, 1856, \$22, p. 39. 
rrencia de un derecho ajeno ${ }^{28}$. La propiedad viene a ser, pues, en palabras de Castán ${ }^{29}$, el centro unitario, autónomo y abstracto de todas las facultades que pudieren recaer sobre la cosa, y al propietario le cabe, bien que sea temporal o circunstancialmente, verse privado de esas facultades, sin dejar por ello de conservar el dominio (es decir, según el diáfano tenor del considerando primero de la STS de 3 de diciembre de $1946^{30}$ — luego reproducido por el considerando primero de la STS de 12 de junio de $1958^{31}$, por el considerando cuarto de la STS de 2 de octubre de $1975^{32}$ o por el fundamento jurídico segundo de la STS de 27 de junio de $1991^{33}$ —, sin perder la integridad potencial de su derecho, «determinante de la posibilidad de recuperación efectiva de todas las facultades dominicales»). Por el contrario, los restantes derechos reales se delimitan fijando positivamente las facultades que corresponden a su titular: cfr. arts. 467 (usufructo), 524 y 526 (uso y habitación), 530 y 533 (servidumbres) ${ }^{34}$.

Insistiendo en esa misma idea, Dusi ${ }^{35}$ expone que la propiedad es «el señorío unitario, independiente y, por lo menos, virtualmente universal sobre una cosa corporal» ${ }^{36}$. Comentando el porqué de la utilización en la definición transcrita del adjetivo independiente, el autor italiano ${ }^{37}$ señala que el dominio, como derecho real por excelencia ${ }^{38}$ o prototípico $^{39}$ (el

${ }^{28}$ Cfr. Roberto De Ruggiero, Instituciones de Derecho Civil, op. cit., p. 523.

29 José Castán Tobeñas, Derecho civil español, común y foral, op. cit., p. 157.

30 RJ 1946/1299.

${ }^{31}$ RJ 1958/2763.

32 RJ 1975/3410.

33 RJ 1991/9821.

34 Cfr. Martin WolfF, Derecho de cosas, op. cit., $\$ 51$, p. 333.

35 Bartolomeo Dusi, Istituzioni di diritto civile, op. cit., p. 329.

36 «La signoria unitaria, indipendente, e almeno virtualmente universale sopra una cosa corporale».

37 Ibid., p. 329.

38 Véanse Calixto Valverde y Valverde, Tratado de Derecho civil español, t. II, 3. ${ }^{a}$ ed. corregida y aumentada, Valladolid, Talleres Tipográficos Cuesta, 1925, p. 33; Leopoldo ALAS ArgüELles, Derecho civil, op. cit., p. 247; Demófilo De BuEN, Derecho civil español común, op. cit., p. 153; Carlos VÁzQuez IRUZubIETA, Doctrina y jurisprudencia del Código Civil, 2. ${ }^{a}$ ed., Madrid, Edersa, 1988, p. 529; Vicente L. Montés Penadés, Comentario del Código Civil, dirigido por Cándido Paz-Ares Rodríguez, Rodrigo Bercovitz, Luis Díez-Picazo Ponce de León y Pablo Salvador Coderch, t. I, Madrid, Ministerio de Justicia, 1991, p. 951; Ángel M. LÓPEZ y LÓPEZ, «El derecho de propiedad. Una relectio», ADC, t. LI, fasc. IV, octubrediciembre de 1998, pp. 1640 o 1679; Adela SERRA Rodríguez, Derecho civil III, coordinado por Adela Serra Rodríguez y José Ramón de Verda y Beamonte, Valencia, Tirant lo Blanch, 2010, p. 121, y Pedro J. Femenía López, Comentarios al Código Civil, dirigido por Rodrigo Bercovitz Rodríguez-Cano, t. II, Valencia, Tirant lo Blanch, 2013, p. 2855.

${ }^{9}$ Cfr. Luis Díez-Picazo y Antonio Gullón Ballesteros, Sistema de Derecho civil, vol. III, t. I, 8. ${ }^{a}$ ed., Madrid, Tecnos, 2012, p. 36. 
máximo ${ }^{40}$ o principal $^{41}$, el paradigmático ${ }^{42}$, el de más alcance y efectivi$\mathrm{dad}^{43}$, el ius in re por antonomasia ${ }^{44}$ ), es perfectamente autónomo, mientras que los otros derechos reales (conocidos como iura in re aliena) se hallan subordinados a la propiedad ajena, y ésta conserva frente a los primeros una preponderancia jurídico-económica. La propiedad, el mayor de los derechos hipotetizables, no puede dimanar de ningún otro derecho subjetivo patrimonial privado, por lo que aquélla se erige como el único derecho real fundante de los demás derechos reales y no fundado por ninguno de ellos ${ }^{45}$. Por consiguiente, a diferencia del dominio, que concede un poder omnicomprensivo ${ }^{46}$, un señorío pleno ${ }^{47}$ sobre el bien, el resto de los derechos reales otorgan sobre dicho bien no más que singulares poderes en orden al provecho que sea capaz de prestar en ciertos aspectos o facetas ${ }^{48}$, id est, sólo proporcionan un señorío parcial. De ahí que se les denomine a éstos derechos reales limitados (o limitativos o frac-

${ }^{40}$ Cfr. Alessandro LevI, Teoria generale del diritto, ristampa anastatica della 2. ${ }^{\text {a ed., }}$ Padova, Cedam, 1967, $\$ 162$, p. 302, y Guillermo CABANELLAS, voz «propiedad», en Diccio-

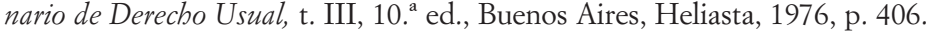

${ }^{41}$ Véase Robert Joseph PotнiER, Traité du droit de domaine, nouvelle édition, Paris, Letellier, 1807, núm. 2, p. 2.

${ }^{42}$ Cfr. José Á. TorRes Lana, Código Civil. Doctrina y jurisprudencia, dirigido por José Luis AlbácAr López, t. II, 1. a ed., Madrid, Trivium, septiembre de 1991, p. 67.

${ }_{43}$ Cfr. el considerando primero de la STS de 21 de noviembre de 1929, Jurisprudencia Civil, t. 191, noviembre-diciembre de 1929, núm. 63.

${ }^{44}$ Cfr. Ignacio Sierra GIL de la Cuesta (coord.), Comentario del Código Civil, t. III, Barcelona, Bosch, 2006, p. 39.

${ }^{45}$ Cfr. Ángel M. LÓPEZ y LÓPEZ, «El derecho de propiedad. Una relectio», op. cit., p. 1679. A lo que añade el mismo autor, en idéntica obra y página: «No obsta a esta conclusión el que se pueda pensar en alguna hipótesis de derecho real limitado no fundado en la propiedad, porque no se está diciendo que sea el único fundante. Por lo demás, los supuestos de derechos reales limitados no basados en una titularidad plena previa son extrañísimos, por no decir inexistentes; piénsese en el ejemplo, de virtualidad puramente escolar, de la adquisición de un derecho real limitado por ocupación, cuya misma posibilidad legal viene puesta en cuestión por los términos del Código Civil».

${ }^{46}$ Cfr. Francesco Messineo, Manual de Derecho civil y comercial, traducción de Santiago Sentis Melendo, t. III, Buenos Aires, Ediciones Jurídicas Europa-América, 1971, $\mathbb{\$} 78$, núm. 11, p. 258.

47 Cfr. Pedro de Pablo Contreras (coord.), Curso de Derecho civil, vol. III, 3. a ed., Madrid, Colex, 2011, pp. 125 y 127. Véanse también José Puig Brutau, Fundamentos de Derecho civil, t. III, vol. I, 4. ${ }^{a}$ ed., Barcelona, Bosch, 1994, p. 132; Jorge RodRíGuEZ-ZAPATA PÉREZ, «La propiedad privada: de cenicienta a derecho fundamental», RGLJ, año CXLVIII, núm. 3, julio-septiembre de 2001, pp. 607 y 613; Jean CARBOnnier, Droit Civil, vol. II, 1. a ed., Paris, Quadrige-Puf, 2004, p. 1642, y Carlos Lasarte Álvarez, Principios de Derecho civil, t. IV, 10. ${ }^{a}$ ed., Madrid, Marcial Pons, 2010, p. 41. Véase también el fundamento jurídico segundo de la STS de 20 de mayo de 1993 [RJ 1993/3807].

${ }_{48}$ Véase Manuel Albaladejo García, Derecho civil, op. cit., p. 232. 
cionarios), no en el sentido de que no sufran límites - porque la propiedad también los tiene-, sino en el de que son de más reducido contenido que el dominio.

Subraya Dusi, asimismo, en su citada definición, que el dominio es un señorío «por lo menos, virtualmente universal», ya que, siendo factible que sobre la cosa propiedad de alguien otra persona ostente un derecho real distinto (usufructo, servidumbre predial, hipoteca, etc.), sin embargo, tal ius in re aliena no conlleva participación en la propiedad (una porción desgajada de esa propiedad) ${ }^{49}$, sino una carga que la comprime, sin quitarle la virtud íntima de reexpandirse y retornar a su natural universalidad ${ }^{50}$; tanto que, cuando se extinga dicho ius in re aliena, la propiedad aparece de nuevo como franca y libre, y también de hecho universal, sin necesidad de que el propietario ejercite un acto de readquisición de aquel derecho real limitado, y sin necesidad siquiera de que el dueño sepa de la referida extinción de éste ${ }^{51}$. Una nota dinámica del dominio a la que se ha bautizado como elasticidad.

Por último, concluye el transalpino, sólo es menester incluir —en la definición que se analiza- las cosas corporales, en atención a que, aplicada a las cosas incorporales, el vocablo propiedad tiene únicamente el significado general de «pertenencia» («appartenenza»o «spettanza») $)^{52}$. Transitando por esta misma senda, hollada también en el pasado por los autores franceses —ad exemplum, Aubry y Rau— ${ }^{53}$ y refrendada en el terreno positivo

${ }^{49}$ Hay que considerar errónea — afirma Díez-Picazo- la tesis que no ve en los iura in re aliena otra cosa que desmembraciones del dominio, «como si, temporalmente, la propiedad saltara en pedazos, constitutivos cada uno de ellos de tales derechos menores, para reconstituirse después, una vez extinguidos aquellos derechos y con perenne vocación a que tal reconstitución se produzca». Cfr. Luis Díez-Picazo, Fundamentos del Derecho civil patrimonial, t. III, 5. ${ }^{a}$ ed., Cizur Menor (Navarra), Thomson-Civitas, 2008, pp. 113-114. Cfr. también Calixto Valverde y Valverde, Tratado de Derecho civil español, op. cit., p. 58.

${ }_{50}$ Bartolomeo Dusi, Istituzioni di diritto civile, op. cit., p. 329.

51 Ibid., pp. 329 y 330.

52 En esa línea, las fuentes hablan del «dominium usus fructus», «dominium servitutis» y «dominium hereditatis». Véase Bartolomeo DusI, Istituzioni di diritto civile, op. cit., p. 330.

${ }^{33}$ Charles AuBrY y Charles Rau, Cours de droit civil français d'après la méthode de Zachariae, t. II, $4 .^{a}$ ed. revisada y puesta al día, Paris, Cosse, Marchal \& Cie, Imprimeurs-Éditeurs, $1869, \mathbb{1} 190$, p. 170. Según ellos, en la acepción verdadera de la palabra, la propiedad no hace referencia sino a las cosas corporales. Sin embargo, el término propiedad se ha extendido a cosas incorporales para designar el derecho exclusivo de usar y disponer de ellas. Cfr., asimismo, Marcel Planiol y Georges RIPERT, Tratado práctico de Derecho civil francés, op. cit., núm. 215, p. 202. 
por el BGB —a través de sus $\$ \$ \$ 903^{54}$ y $90^{55}$ —, suscribirá entre nosotros López y López ${ }^{56}$ que en una acepción rigurosa, en el plano técnico-jurídico, sólo puede entenderse por propiedad el señorío (con la amplitud ${ }^{57}$ que determine cada particular estatuto en función preferentemente del objeto) que se proyecte sobre cosas materiales. Ergo, sólo de un modo traslaticio - casi cual recurso o expediente verbal — es imaginable hablar de propiedades sobre bienes inmateriales.

En el seno del Código Civil español, su art. 348 (influenciado por la ideología liberal francesa) conceptúa —en su primera parte- la propiedad como «el derecho de gozar y disponer de una cosa, sin más limitaciones que las establecidas en las leyes» ${ }^{58}$. Esta definición legal, sin escapar del afán descriptivo, simplifica o aligera ${ }^{59}$ la enumeración de facultades que en el derecho de propiedad pueden albergarse ${ }^{60}$, englobándolas en

54 «El propietario de una cosa, en tanto que no sea contrario a la ley o a los derechos de terceros, puede proceder con la cosa según su voluntad y excluir a otros de toda intromisión en ella. El propietario de un animal debe observar, en el ejercicio de sus facultades, las disposiciones especiales sobre protección de animales». Cfr. Código Civil alemán y ley de introducción al Código Civil, traducción de Albert Lamarca Marqués, Madrid, Marcial Pons, 2008, p. 253. Según la doctrina liberal, había que evitar —escribe Hattenhauer — la sensación de que el propietario tenía que usar su cosa ateniéndose a unas reglas determinadas, o incluso que estuviera obligado en absoluto a hacer uso de ella. «Formaba parte de la libertad del propietario que el legislador no pudiera ponerle andaderas». Cfr. Hans HatTenHauer, Conceptos fundamentales del Derecho civil. Introducción histórica y dogmática, traducción de

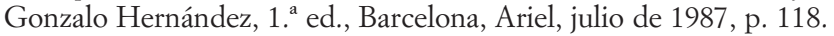

55 «Cosas en sentido legal sólo son los bienes corporales». Cfr. Código Civil alemán y ley de introducción al Código Civil, op. cit., p. 50.

56 Ángel M. LóPEZ y LóPEZ, La disciplina constitucional de la propiedad privada, Madrid, Tecnos, 1988, p. 40. Cfr. también José CASTÁN TOBEÑAs, La propiedad y sus problemas actuales, 2. ${ }^{\text {a }}$ ed. revisada y ampliada, Madrid, Instituto Editorial Reus, 1963, pp. 67 y ss., y Martin WolfF, Derecho de cosas, op. cit., $\$ 51$, pp. 330-331.

57 Cfr., asimismo, Manuel Peña Bernaldo de Quirós, Derechos reales. Derecho hipoteca-

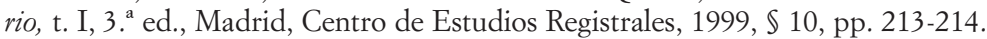

${ }^{58}$ Es igual al art. 350 del Anteproyecto de 1882-1888. El art. 391 del Proyecto de 1851 prescribía que: «La propiedad es el derecho de gozar y disponer de una cosa sin más limitaciones que las que previenen las leyes o reglamentos». Cfr. Florencio García Goyena, Concordancias, motivos y comentarios del Código Civil español, op. cit., p. 351. En el art. 621 del Proyecto de 1836 podía leerse: «Propiedad es el derecho que uno tiene sobre sus cosas para disponer de ellas a su arbitrio, con tal que no haga un uso prohibido por las leyes o pactos». Cfr. Ángel Fernando Pantaleón Prieto, «La libertad del dominio», en VVAA, Propiedad y Derecho civil, Madrid, Colegio de Registradores de la Propiedad y Mercantiles de España, 2006, p. 61. Añade tal art. 348 CC, en su segunda parte, que «el propietario tiene acción contra el tenedor y el poseedor de la cosa para reivindicarla».

59 Véase Manuel Albaladejo García, Derecho civil, op. cit., pp. 234-235. Cfr. también Luis Díez-PICAZO, «Propiedad y Constitución», op. cit., p. 14.

${ }^{60}$ Ius utendi, ius fruendi, ius abutendi, ius innovandi, ius possidendi, ius disponendi, ius vindicandi, ius custodiandi. Cabe, incluso, especificar aún más, y así invocar, por ejemplo, las facul- 
dos: la de gozar y la disponer del bien. Dicha caracterización — como pone de relieve Scaevola— ${ }^{61}$ es, en el fondo, la misma definición latina recogida renglones atrás ${ }^{62}$, «ius utendi et abutendi re sua quatenus iuris ratio patitur», y similar a la aposentada en la ley 1. ${ }^{a}$, título XXVIII, partida 3. ${ }^{a}$ : «Señorío es poder que ome há en su cosa de fazer de ella, o en ella, lo que quisiere segund Dios e segund fuero» ${ }^{63}$. En efecto, el ius utendi es igual al "derecho de gozar" de nuestro Código, «admitiendo la misma equivalencia tanto el ius abutendi y "derecho de disponer", como las frases "limitaciones que impongan las leyes" y la "quatenus iuris ratio patitur", que el Rey Sabio tradujo por la de "segund Dios e segund fuero", dándola así, por tanto, significación más extensiva» ${ }^{64}$.

Este art. 348 del Código Civil español ${ }^{65}$ trae directa causa del art. 544 de su homólogo napoleónico ${ }^{66}$, aunque se descubren básicamente dos palmarias diferencias ${ }^{67}$ de redacción entre ambos preceptos: en nuestra norma no se alude al goce y a la disposición de la cosa «del modo más absoluto» ${ }^{68}$

tades de gravar, transformar, destruir (etc.) la cosa, o la de excluir a los demás de la misma, o incluso -como evidencia Pantaleón - un ius acquirendi thesaurus (art. 351-I CC). Cfr. Ángel Fernando Pantaleón PRieto, «La libertad del dominio», op. cit., p. 63. Cfr. también nota 14.

${ }^{61}$ Q. Mucius Scaevola, Código Civil comentado y concordado extensamente, op. cit., pp. 453 y 454.

${ }_{62}$ Cfr. nota 12 de este trabajo.

63 Véase Las Siete Partidas de Alfonso X el Sabio (El Libro del Fuero de las Leyes), introducción y edición dirigida por José SÁnchez-Arcilla Bernal, Madrid, Reus, 2004, pp. 567-568; así como el comentario al respecto de Gregorio López De Tovar, Las Siete Partidas, t. III, Salamanca, A. de Portonariis, 1555, ad l. 1, tít. XXVIII, P. 3. a, glosa e), fol. 155v. Cfr. también el considerando primero de la citada STS de 21 de noviembre de 1929, Jurisprudencia Civil, t. 191, noviembre-diciembre de 1929, núm. 63.

${ }^{64}$ Q. Mucius Scaevola, Código Civil comentado y concordado extensamente, op. cit., p. 454.

${ }^{65}$ Que, como asegura Torres Lana, mantiene un «aspecto saludable». Cfr. José Á. Torres Lana, Código Civil. Doctrina y jurisprudencia, op. cit., p. 68.

${ }^{66}$ «La propriété est le droit de jouir et disposer des choses de la manière la plus absolue, pourvu qu'on n'en fasse pas un usage probibé par les lois ou par les règlements». El texto de este art. 544 condensa — resalta Montés Penadés - unas corrientes de pensamiento filosófico, económico y jurídico: el iusnaturalismo racionalista templado por el empirismo de Locke, la visión económica de los fisiócratas, la aportación de los grandes juristas (especialmente los galos) de los siglos XVII y XVIII. Cfr. Vicente L. Montés Penadés, La propiedad privada en el sistema del Derecho civil contemporáneo (un estudio evolutivo desde el Código Civil hasta la Constitución de 1978), 1. a ed., Madrid, Civitas, 1980 p. 51.

${ }^{67}$ Montés Penadés las llama «variantes significativas». Cfr. Vicente L. Montés PenADÉs, La propiedad privada en el sistema del Derecho civil contemporáneo (un estudio evolutivo desde el Código Civil hasta la Constitución de 1978), op. cit., p. 62, e íD., Comentarios al Código Civil, op. cit., p. 149.

${ }_{68}$ Cfr. Ricardo MiñarRo Montoya, «La propiedad desde el punto de vista del Derecho civil: limitaciones del derecho de propiedad», en VVAA, Propiedad y Derecho civil, Madrid, 
(muy loable opción legislativa ${ }^{69}$, y tampoco se cita en el texto patrio a «los reglamentos» (sí lo hacía el art. 391 del Proyecto de 1851) ${ }^{70}$ como venero de limitaciones de las facultades del dueño.

En lo concerniente a la primera disimilitud, repárese en que cuando el Code en sus arts. $544^{71}$ y $545^{72}$ refleja que la propiedad es el derecho de gozar y disponer de una cosa del modo más absoluto ${ }^{73}$, sin otras limitaciones que las legales, y que nadie puede ser despojado de su propiedad sino por la expropiación, fundada en causa justificada de utilidad pública y previa la necesaria indemnización, en verdad positiviza uno de los resultados de la Revolución de $1789^{74}$ : la propiedad libre de las cargas feudales del Ancien Régime; la autonomía de la voluntad del individuo, anhelo del liberalismo burgués, que es el que sale fortalecido de la Revolución; la persistencia y consagración de las propiedades adquiridas durante el movimiento revolucionario de los bienes denominados nacionales (de la Iglesia, de la nobleza, etc. $)^{75}$. El ambiente reinante en la época de redacción del Código Civil español era, asimismo, de cariz liberal, pero no requería ya de retórica alguna — recuerdan Díez-Picazo y Gullón- para triunfar como en la

Colegio de Registradores de la Propiedad y Mercantiles de España, 2006, p. 241, y Carlos Lasarte Álvarez, Principios de Derecho civil, op. cit., pp. 38 y 42.

${ }^{69}$ Véase, por ejemplo, Diego EsPín CÁnovas, Manual de Derecho civil español, op. cit., p. 69. Cfr. también el considerando tercero de la STS de 20 de octubre de 1941 [RJ 1941/1087] o el considerando segundo de la STS de 23 de diciembre de 1946 [RJ 1946/1413].

${ }^{70}$ Véase nota 58.

${ }^{71}$ Véase nota 66.

72 «Nul ne peut être contraint de céder sa propriété, si ce n'est pour cause d'utilité publique, et moyennnant une juste et préalable indemnité».

73 Pothier ya había sugerido que «ce droit de propriété, consideré par rapport à ses effets, doit se definir le droit de disposer à son gré d'une chose sans donner néanmoins atteinte au droit d'autroui, ni aux lois: ius de re libere disponendi, ou ius utendi et abutendi». Cfr. Robert Joseph PотніER, Traité du droit de domaine, op. cit., núm. 4, p. 5.

${ }^{74}$ El objetivo fundamental del Código de Napoleón fue el de estabilizar el régimen de propiedad derivado de la Revolución Francesa, calificándolo cual derecho absoluto, luego de que en la Declaración de los Derechos del Hombre y del Ciudadano de 1789 la propiedad hubiese sido colocada entre los derechos naturales e imprescriptibles. Ello implica otorgar explícitamente a la propiedad un rango central en el sistema jurídico. Todas las demás instituciones aparecen subordinadas a ella. Cfr. Rodrigo BerCovitz Rodríguez-Cano, Qué es la propiedad, Barcelona, La Gaya Ciencia, 1977, pp. 7 y ss. Según el art. 17 de tal Declaración de Derechos del Hombre y del Ciudadano: «La propriété étant un droit inviolable et sacré, nul ne peut en être privé, si ce n'est lorsque la nécessité publique, légalement constaté, l'éxige évidemment, et sous la condition d'une juste et préalable indemnité». Puede consultarse en http://www.legifrance.gouv.fr/Droit-francais/Constitution/Declaration-des-Droits-de-lHomme-et-du-Citoyen-de-1789. Véase también el art. II-77.1 de la Constitución Europea.

${ }^{75}$ Cfr. Luis Díez-Picazo y Antonio Gullón Ballesteros, Sistema de Derecho civil, op. cit., p. 141. 
Revolución Francesa: se vivía, si bien el principio de su decadencia se acercaba, y por ello no se incluye en nuestro art. 348 el sintagma francés «del modo más absoluto» ${ }^{76}$.

En lo que toca a la segunda desemejanza, la que atañe a las limitaciones, hay que tomar, no obstante, la voz «leyes» en un sentido amplio, por lo que comprende no sólo las leyes propiamente dichas, sino también las disposiciones reglamentarias y administrativas ${ }^{77}$. De todo ello se hace oportuno eco el enjundioso considerando primero de la STS de 22 de enero de $1914^{78}$, al constatar que «si bien es esencia y atributo peculiar del dominio que aquel a quien pertenece una cosa puede disponer de ella libremente, esta facultad no reviste caracteres absolutos y omnímodos ${ }^{79}$, en razón a que toda propiedad se subordina siempre a limitaciones determinadas ${ }^{80}$, ya por las leyes, ya por pactos convenidos o por costumbres establecidas y aceptadas, en cuya virtud ha de amoldarse a unas u otros el ejercicio de tal dominio».

La definición de propiedad residenciada en el art. 348 CC, tras un detallado examen, ha sido blanco de críticas doctrinales desde dos enfoques o puntos de vista:

Desde la óptica técnica, se reprueba ${ }^{81}$ que configure el derecho de propiedad de forma fragmentada - a guisa de una más o menos bien hilvana-

${ }^{76}$ Ibid., p. 141. Véase también Vicente L. Montés Penadés, La propiedad privada en el sistema del Derecho civil contemporáneo (un estudio evolutivo desde el Código Civil hasta la Constitución de 1978), op. cit., p. 50.

77 Cfr. José Castán Tobeñas, Derecho civil español, común y foral, op. cit., p. 162. Véase, asimismo, José María MANResa y NAVARRo, Comentarios al Código Civil español, op. cit., p. 195.

${ }^{78}$ Jurisprudencia Civil, t. 129, enero-mayo de 1914, núm. 35.

79 Como resumen Pérez González y Alguer en las anotaciones al Derecho de cosas: «Puede decirse [...] que no se puede definir la propiedad como un "derecho de suyo ilimitado", y que [...] no puede deducirse del simple concepto de propiedad cuál es el límite hasta el que llega la libertad del propietario para proceder a su antojo, sino que ello resulta del conocimiento del ordenamiento jurídico total que delimita lo que es contenido del derecho subjetivo». Cfr. Martin WolfF, Derecho de cosas, op. cit., $\mathbb{\$} 51$, pp. 332 y 333.

${ }^{80}$ Es dable traer a colación aquí la relatividad histórica de las concepciones y regulaciones de la propiedad como algo consustancial o inherente a la misma. Todos los regímenes han condicionado y regulado la institución dominical. La han restringido, por ejemplo, en provecho de la propia colectividad, al menos la referente a ciertos bienes (así, la propiedad tribal de la tierra o el dominio socializado de los medios de producción); la han reservado, en otros casos, a una elite de los integrantes del cuerpo social (a quienes se atribuía la propiedad fundiaria) con exclusión de los demás o de los miembros de alguna minoría étnica o religiosa. El entramado feudal de la Edad Media distinguió varios niveles del dominio atribuyéndoselos a Dios (dominium principale), al soberano (dominium eminens), a su vasallo feudal (dominium directum) y al siervo que disfrutaba del bien y lo trabajaba (dominium utile). Cfr. Jorge RoDRíGUEz-ZAPATA PÉREZ, «La propiedad privada: de cenicienta a derecho fundamental», op. cit., pp. 606-607.

${ }^{81}$ Véase, por ejemplo, Pedro J. Femenía López, Comentarios al Código Civil, op. cit., p. 2856. 
da fusión o congregación de facultades- y no con ánimo unitario ${ }^{82}$, cual poder general y abstracto.

En lo atinente a esta cuestión, se afirma, en primer lugar, que la literalidad del art. 348 CC no sirve para definir el dominio, habida cuenta de que las facultades de goce y de disposición no son exclusivas de la propiedad, salvo — como apostillan, entre otros, Blasco Gascó y Cecchini Rosell— ${ }^{83}$ que se caiga en el pleonasmo de precisar que se trata de un goce ut domino y de una disposición también ut domino, o sea, que se hable de un derecho a gozar como propietario ${ }^{84} \mathrm{y}$ a disponer como propietario de una $\cos ^{85}$. Y ello es así porque un goce sin apellidos, un goce

82 Según recoge el fundamento jurídico segundo de la STS de 27 de junio de 1991 [RJ 1991/9821]: «Teniendo el dominio un contenido unitario, global y elástico, distinto de sus facultades, no puede haber incompatibilidad entre la propiedad y la atribución del ejercicio de alguna de esas facultades a persona distinta». Véase también Alfonso QuARANTA, Commentario teorico-pratico al Codice Civile, libro III, Della proprietà. Beni e proprietà in generale (art. 810-870), dirigido por Vittorio DE MARTino, 1. a ed., Novara-Roma, Edizioni Pem, 1970, p. 250.

83 Francisco de Paula Blasco Gascó y Xavier Cecchini Rosell, Comentarios al Código Civil, coordinado por Joaquín Rams AlBesa, t. III, Barcelona, Bosch, 2001, p. 98. Cfr., asimismo, Pedro J. Femenía López, Comentarios al Código Civil, op. cit., p. 2857, y Vicente L. Montés Penadés, La propiedad privada en el sistema del Derecho civil contemporáneo (un estudio evolutivo desde el Código Civil hasta la Constitución de 1978), op. cit., pp. 248-252.

${ }_{84} \mathrm{Al}$ intento de caracterizar el goce $u t$ dominus sería conveniente partir de la faz interna — señala Montés Penadés - de la posición de ventaja del dueño, entendiendo que no cualquier tipo de goce, y menos un goce de hecho, realizaría ese interés. El goce del propietario sería el presupuesto de utilización de las acciones denominadas reales, y no conllevaría el ejercicio de la acción de responsabilidad extracontractual, que no protege un goce de carácter específico, sino que sirve para la sanción frente a cualquier tipo de daño padecido por cualquier persona, dueño o no, que se halla en relación con la cosa. Cfr. Vicente L. MonTÉs PENADÉs, La propiedad privada en el sistema del Derecho civil contemporáneo (un estudio evolutivo desde el Código Civil hasta la Constitución de 1978), op. cit., p. 248. El objeto del licere del dueño no es un tipo de goce — continúa el jurista-, sino una orden, una decisión, sobre el goce. Mientras que el usufructuario, al igual que otros titulares de derechos reales limitados, ha de respetar el destino (y esto no conforma una verdadera obligación, sino un límite o elemento caracterizador de su poder), para el propietario carece de relevancia el acto jurídico de destino preestablecido, que puede alterar, o desconocer, y no tiene el deber de respetar. El interés del propietario se tiene que configurar, pues, como un interés en la elección del tipo de goce o de los posibles destinos de la cosa, interés que no se encuentra protegido en ninguna de las clases de derecho de goce. Así, incumbe al dueño la competencia (exclusiva) de fijar, de manera independiente y autónoma, el tipo de goce, elección que puede ser hecha de modo pleno, esto es, en cualquier dirección deseada por él. Cfr. ibid., pp. 248 y 249.

${ }^{85}$ Quizá - preconiza Montés Penadés- la mejor caracterización de la facultad de disposición en cuanto contenido del dominio podría ser la de estimarla como un elemento normal, mas no esencial, del derecho subjetivo de propiedad, porque no puede descartarse, a priori, que en ciertos casos el ejercicio del derecho, esto es, de la facultad de disposición, represente para el propietario el modo esencial de disfrute del propio bien (por ejemplo, en 
a secas, es contenido presente también en otros derechos subjetivos, personales cual el arrendamiento, o reales como el usufructo, de suerte que no vale para diferenciar de esos otros derechos a la propiedad plena. El derecho de disponer, por su parte, resulta equívoco ${ }^{86}$, ya que de disposición jurídica son capaces todos los derechos alienables. Y la facultad de vindicar o reclamar tampoco se revela como privativa del dominio, pues caracteriza - lo resalta Lacruz — ${ }^{87}$ a cualquier derecho sobre la cosa; al margen de que ella no es en puridad una facultad, sino el mismo dominio (o derecho limitado) en acción.

Se rechaza igualmente, en segundo lugar, tal concepción enumerativa del dominio, porque se antoja baldío el propósito de agrupar con exhaustividad — como se declaró al comienzo de estos folios- todas y cada una de las múltiples posibilidades de actuación del dominus sobre la $\operatorname{cosa}^{88}$. Las facultades inherentes a la propiedad quedan, pues, sintetizadas —aseveran Aubry y Rau- ${ }^{89}$ en esta proposición: el propietario puede ad líbitum usar y disfrutar de su cosa, disponer materialmente de ella, realizar a su vez todos los actos jurídicos de que ella es susceptible, así como excluir a terceros de cualquier participación en el ejercicio de dichas facultades ${ }^{90}$ (ius excludendi alios). La médula, por tanto, del art. 348 CC, en aras a delinear el derecho de propiedad, no reside en

el caso de bienes destruidos, como sería el supuesto, por desgracia frecuente, de los bosques quemados). «Por eso - acaba - algunos autores han considerado que la facultad de disposición es una extensión del derecho de goce, y más exactamente su consecuencia extrema, esto es, algo así como la causa que legitima la actividad del sujeto inherente al goce del derecho, extendida hasta el extremo de excluir la relación de sí mismo para hacer subentrar a otro sujeto». Cfr. Vicente L. Montés PenAdÉs, La propiedad privada en el sistema del Derecho civil contemporáneo (un estudio evolutivo desde el Código Civil hasta la Constitución de 1978), op. cit., p. 251. Véase también Ángel M. LóPEZ y LóPEZ, Código Civil comentado, coordinado por Pedro de Pablo Contreras y Rosario Valpuesta Fernández, vol. I, 1. a ed., Cizur Menor (Navarra), Civitas-Thomson Reuters, 2011, p. 1404.

${ }^{86}$ Cfr. José Luis Lacruz Berdejo, Elementos de Derecho civil, t. III, vol. I, 3. a ed. revisada y puesta al día por Agustín Luna Serrano, Madrid, Dykinson, 2008, $\mathbb{D} 21$, núm. 103, p. 238.

${ }^{87}$ Ibid., $\$ 21$, núm. 103, p. 238.

${ }^{88}$ Véase, por ejemplo, Manuel Albaladejo García, Derecho civil, op. cit., p. 234.

${ }^{89}$ Charles AuBrY y Charles RAu, Cours de droit civil français d'après la méthode de Zachariae, op. cit., $\mathbb{\$} 190$, p. 169.

${ }^{90}$ Dicha proposición descriptiva comprende, en sentido positivo, los actos materiales (aprovechamiento: goce o consumo) y los actos jurídicos (administración y disposición), mientras que en sentido negativo destaca la exclusión de los demás en la relación del sujeto con el objeto del derecho de propiedad. Véase Xavier O'Callaghan Muñoz, Compendio de Derecho civil, t. III, 1. ${ }^{a}$ ed., Madrid, Editorial Universitaria Ramón Areces, septiembre de 2012, p. 47. 
la enunciación de facultades, sino en el aditamento «sin más limitaciones (recte: límites ${ }^{91}$ ) que las establecidas en las leyes», que significa una especie de abandono por el legislador de todo intento de delimitar positivamente el dominio ${ }^{92}$. Tráigase a las mientes también, al respecto, que el Código Civil español cuenta con un título ad hoc para la regulación «de algunas propiedades especiales» (título IV del libro II, arts. 407 y ss.), lo que confirma la aceptación por nuestro legislador de lo obvio: el contenido del derecho de propiedad requería ponderar la naturaleza de los bienes sobre los que el derecho subjetivo recae; esto es, la asunción de la famosa visión pluralista de la propiedad ${ }^{93}$.

Finalmente, y en estrecha relación con lo anterior, tampoco - explana un sagaz Lacruz- ${ }^{94}$ una enumeración completa, pormenorizada, de las facultades que comporta expresaría la esencia de la propiedad, porque este derecho puede prescindir ocasionalmente de muchas de ellas. Además, en una situación como la hodierna, en la que el interés privado se halla sujeto al público en tantos aspectos, las facultades varían según la índole de la cosa objeto de la propiedad (edificaciones, prados, árboles, solares, obras de arte, etc.), sin que por ello se altere la naturaleza del derecho, cuyas facultades no son un prius, sino un posterius ${ }^{95}$ : cobrando vida a partir de la propiedad, por lo cual no habrían de servir para definirla.

Desde el marco político-social se le reprocha al art. 348 CC que encierre una idea «clásica» y eminentemente individualista de la propiedad, en una época en la que ya despuntaba la tendencia hacia un concepto más

${ }^{91}$ Ha sido la doctrina germana la que, desde Gierke, empezó a distinguir entre delimitación de la propiedad dentro de unos límites, que marcan su contenido normal (Eigentumsbegrenzung), y las limitaciones que reducen o condicionan en casos singulares o especiales tal contenido (Eigentumbeschräkungen). Cfr. Manuel Albaladejo García, Derecho civil, op. cit., pp. 232 y ss., y Xavier O'Callaghan Muñoz, Compendio de Derecho civil, op. cit., p. 71.

${ }_{92}$ Cfr. Martin Wolff, Derecho de cosas, op. cit., $\$ 51$, p. 333.

93 Véase Carlos Lasarte Álvarez, Principios de Derecho civil, op. cit., p. 42. No hay que negar — razona el mismo autor — «el valor de la propiedad privada como pilar básico del sistema económico imperante en la mayor parte de las sociedades desarrolladas, ni convertir al propietario en mero administrador de sus bienes. [Sólo es menester] subrayar que la regulación normativa del contenido de la propiedad (tarea, pues, del legislador) se asienta realmente en la valoración del significado y naturaleza de los distintos grupos de bienes que, en cada momento histórico, puedan identificarse, y no en una predeterminación de las facultades del propietario conforme a la definición liberal del dominio» (p. 45). Cfr. también el fundamento jurídico cuarto de la STC de 17 de marzo de 1994 [RTC 1994/89]. p. 238.

${ }^{94}$ José Luis Lacruz Berdejo, Elementos de Derecho civil, op. cit., \$21, núm. 103,

${ }^{95}$ Cfr. también, en punto a ello, Felipe Clemente DE DIEGO, Instituciones de Derecho civil español, op. cit., p. 314. 
social de aquélla ${ }^{96}$. En respuesta a la evolución de los tiempos, la actual normativa inserta el interés de la colectividad en el concepto mismo de propiedad $^{97}$. Así, el art. 33 de la Constitución, luego de proclamar —en su apartado 1 - que «se reconoce el derecho a la propiedad privada y a la herencia», añade —en el segundo- que «la función social de estos derechos delimitará su contenido de acuerdo con las leyes». Y no se trata de un mero límite externo a la noción de propiedad, sino que constituye una parte ${ }^{98}$ del derecho mismo (cfr. el fundamento jurídico segundo de la STC de 26 de marzo de 1987) ${ }^{99}$.

Debe descartarse —recalcan Díez-Picazo y Gullón- ${ }^{100}$, empero, que la Constitución arranque del presupuesto de que el propietario sea un simple gestor de lo que los poderes públicos decidan, porque si así fuera carecería de sentido el reconocimiento de la propiedad priva$\mathrm{da}^{101}$. Por función social hemos de considerar, con apoyo en el art. 128.1

${ }^{96}$ Se le critica igualmente el hablar de propiedad — siendo ésta una relación meramente económica- y no de derecho de propiedad. Cfr. Diego Espín Cánovas, Manual de Derecho civil español, op. cit., p. 69, y José CASTÁn TOBEÑas, Derecho civil español, común y foral, op. cit., p. 163.

${ }_{97}$ Cfr. Germán Bercovitz Álvarez, Comentarios al Código Civil, coordinado por Rodrigo Bercovitz Rodríguez-Cano, 3. a ed., Cizur Menor (Navarra), Aranzadi-Thomson Reuters, 2009, p. 496.

98 Ya había apuntado San Juan XXIII en la Encíclica Mater et Magistra que: «Al derecho de propiedad privada sobre los bienes le es intrínsecamente inherente una función social», y que «la función social de la propiedad privada surge de la naturaleza misma del derecho de propiedad». Cfr. la edición de esta Encíclica publicada por la Oficina de Coordinación y Programación Económica, utilizando la traducción castellana hecha por la Tipografía Políglota Vaticana, Madrid, 1961, p. 43.

99 «La Constitución reconoce un derecho a la propiedad privada que se configura y protege, ciertamente, como un haz de facultades individuales sobre las cosas, pero también, y al mismo tiempo, como un conjunto de deberes y obligaciones establecidos, de acuerdo con las leyes, en atención a valores o intereses de la colectividad, es decir, a la finalidad o utilidad social que cada categoría de bienes objeto de dominio esté llamada a cumplir. Por ello, la fijación del "contenido esencial" de la propiedad privada no puede hacerse desde la exclusiva consideración subjetiva del derecho o de los intereses individuales que a éste subyacen, sino que debe incluir igualmente la necesaria referencia a la función social, entendida no como mero límite externo a su definición o a su ejercicio, sino como parte integrante del derecho mismo. Utilidad individual y función social definen, por tanto, inescindiblemente el contenido del derecho de propiedad sobre cada categoría o tipo de bienes» [RTC 1987/37].

${ }^{100}$ Luis Dímz-Picazo y Antonio Gullón Ballesteros, Sistema de Derecho civil, op. cit., p. 144.

${ }^{101}$ La propiedad ha sido un elemento capital en la configuración constitucional clásica, hasta el extremo de ser elevada a la categoría de uno de sus principales fundamentos y convertida en una de las piezas maestras de la conocida como «constitución material». Recuérdese — como hace López y López - la íntima conexión de la codificación constitucional liberal con la codificación civil, carta magna de la propiedad privada. Y aun cuando esto 
de aquel texto, que se halla supeditada al interés general ${ }^{102} \mathrm{o}$, con palabras de mayor raigambre histórica, al bien común ${ }^{103}$. En suma - como advierte el formidable considerando primero de la STS de 21 de febrero de 1981— ${ }^{104}$, «por mucho que se enfatice sobre la mutación sufrida por el derecho de propiedad [...] hasta convertirse en derecho de los llamados estatutarios, su declinación, respecto del sentido que ha tenido en sus momentos de mayor esplendor, en los que le estaba permitido, en su ejercicio, hasta el ius abutendi, no puede llegar al extremo de reducirlo a un derecho inerme, totalmente sometido a cuantas prohibiciones tengan a bien adoptar las distintas autoridades administrativas [...] y no puede

corresponda en no poca medida al pasado, y la disciplina de la propiedad aparezca hoy despojada de aquella veste de sacralidad que lucía antaño, se ha de tener in mente que el sistema de relaciones sociales sobre el que se edifica nuestra actual Constitución reposa en un orden económico inconcebible sin la propiedad. Cfr. Ángel M. LóPEz y López, La disciplina constitucional de la propiedad privada, op. cit., p. 29.

${ }_{102}$ Como indica el párrafo 8 de la Exposición de Motivos de la Ley 8/1984, de 3 de julio, de Reforma Agraria de la Comunidad Autónoma de Andalucía [BOJA de 6 de julio de 1984]: «Se puede decir, con práctica aceptación general, que la función social de la propiedad supone la incorporación de la perspectiva del deber al derecho subjetivo, deber que modaliza su ejercicio; ejercicio que se aboca a la búsqueda de un logro social, que al mismo tiempo preserve el poder del titular».

${ }^{103}$ Cfr. Luis Díez-Picazo y Antonio Gullón Ballesteros, Sistema de Derecho civil, op. cit., pp. 144-145. El propio Díez-Picazo, esta vez en solitario, enhebra luminosamente el siguiente argumento: «Mi opinión siempre ha sido que el art. 33 hay que relacionarlo indeclinablemente con el art. 128 [ambos de la CE]. Según este último artículo, "toda la riqueza del país en sus distintas formas y sea cual fuere su titularidad está subordinada al interés general" y, además, "se reconoce la iniciativa pública en la actividad económica" y, "mediante ley se podrá reservar al sector público recursos o servicios esenciales, especialmente en caso de monopolio, y, asimismo, acordar la intervención de empresas cuando así lo exigiere el interés general". De esta manera, y por lo que se refiere al derecho de propiedad privada, parece bastante claro que no sería constitucionalmente suficiente un sistema jurídico y económico donde sólo se reconociera alguna variante de la propiedad privada. Por utilizar el lenguaje de lo que hace años se denominaban sistemas del socialismo real, en ellos se solía distinguir la propiedad de los bienes de producción, que se colocaba en manos de las organizaciones del pueblo trabajador, y la llamada propiedad personal, de la que se excluían, naturalmente, los bienes de producción. En este sentido, cuando el art. 33 en relación con el art. 128 dice "propiedad privada" y entendemos esta última como una pieza de la constitución económica, debemos entender que está diciendo que se pueden reservar al sector público recursos, pero se está admitiendo un sistema jurídico y económico en el que la propiedad privada se refiere a los bienes de producción, como por lo demás se deduciría igualmente del reconocimiento de la libertad de empresa y de la libertad de iniciativa económica y, en aquella parte en que la propiedad privada es un soporte de la libertad individual, de la dignidad de la persona proclamada por el art. 10 [CE]». Cfr. Luis Díez-PICAZO, «Propiedad y Constitución», op. cit., pp. 17-18. Cfr. también el considerando primero de la lejana STS de 17 de noviembre de 1930 [RJ 1930/1265].

104 RJ 1981/1147. 
llegar a estos extremos porque la propiedad del particular sigue siendo algo más que una simple función pública o social, puesto que conserva su núcleo primario de derecho subjetivo, uno de los principales de los que integran la constelación de derechos de la personalidad, amparado en la cobertura legal que proporciona el Código Civil (arts. 348, 349 y 350) y la propia Constitución española (art. 33)».

Por otro lado, la Constitución coloca el derecho de propiedad dentro de la sección 2. ${ }^{a}$ del capítulo II del título I, mas no en la sección $1 .{ }^{a}$, que se ocupa, según su rúbrica, de «los derechos fundamentales y de las libertades públicas» ${ }^{105}$. Tal ubicación es relevante para el Tribunal Constitucional, pues de ella se deriva la consecuencia de un más o menos acusado rigor protector a la luz del art. 53 de la misma Constitución ${ }^{106}$. Además, como el art. $33 \mathrm{CE}$ termina con un apartado (expresión constitucional del art. 349 CC) que impide que pueda el titular ser privado de sus bienes y derechos salvo por causa justificada de utilidad pública o interés social (causa expropiandi) ${ }^{107}$, y siempre mediante la correspondiente indemnización y conforme a lo dispuesto por las leyes, el Tribunal Constitucional juzga, en el fundamento jurídico octavo de su Sentencia de 2 de diciembre de $1983^{108}$, que la propiedad es «como un derecho subjetivo, debilitado, sin embargo, por cuanto cede para convertirse en un equivalente económico, cuando el bien de la comunidad, concretado en el art. 33.3 [CE] por la referencia a los conceptos de utilidad pública o interés social, legitima la expropiación».

En el ámbito ya de los caracteres esenciales del derecho de propiedad (junto a la generalidad, abstracción, exclusividad o perpetuidad) ${ }^{109}$, suele

${ }^{105}$ Este derecho del art. 33 CE se encuadra en la sección 2. ${ }^{a}$ del capítulo II del título I, entre los «derechos de los ciudadanos», y por ello, conforme al art. 53.1 CE, sus mecanismos de protección son: la reserva de ley, el respeto a su contenido esencial y el recurso de inconstitucionalidad del art. 161.1.a) CE. No es, por tanto, uno de los derechos fundamentales (sección 1.a) que están dotados de mayor protección de acuerdo con el art. 53.2 CE. Véase sobre la cuestión Adela SERRA RodríGUEz, Derecho civil III, op. cit., p. 122.

106 Véase Luis Díez-Picazo y Antonio Gullón Ballesteros, Sistema de Derecho civil, op. cit., p. 145. Cfr. también Xavier O'Callaghan Muñoz, Compendio de Derecho civil, op. cit., p. 48.

${ }_{107}$ Cfr. Ricardo MiÑarro Montoya, «La propiedad desde el punto de vista del Derecho civil: limitaciones del derecho de propiedad», op. cit., pp. 250-251.

108 RTC 1983/111.

109 Véase, por ejemplo, Xavier O'Callaghan Muñoz, Compendio de Derecho civil, op. cit., pp. 48 y 49. Lacruz Berdejo, con otro criterio, incluye en los caracteres esenciales del dominio la vocación de generalidad, la abstracción y la elasticidad, mientras que - a su juicio- la exclusividad y la perpetuidad son atributos de dicho dominio. Cfr. José Luis LACRUZ BERDEJo, Elementos de Derecho civil, op. cit., $\ 21$, núm. 104, pp. 238-242. De los Mozos añade a los atributos la nota de absolutividad. Los caracteres de la propiedad se deducen - 
decirse también, a semejanza de lo que se predica en el campo de la física respecto a los materiales - a los que se califica de elásticos en mayor o menor grado- ${ }^{110}$, que el dominio participa de una indudable elasticidad $^{111}$. De acuerdo con el Diccionario de la Real Academia Española de la Lengua, por elasticidad —o cualidad de elástico — hemos de entender la «propiedad general de los cuerpos sólidos, en virtud de la cual recobran más o menos completamente su extensión y forma, tan pronto como cesa la acción de la fuerza que las deformaban» ${ }^{112}$. Lo que la distingue manifiestamente de la llamada plasticidad, pues plástico se define por el mismo Diccionario como el objeto que, «mediante una compresión más o menos prolongada, puede cambiar de forma y conservar esta de modo permanente, a diferencia de los cuerpos elásticos» ${ }^{113}$.

Tradúcese la elasticidad dominical en que, si carece la propiedad de alguna (o varias) de sus facultades (se le arrebatan al dueño, por ejemplo, la facultad de gozar — ahora — y la de disponer), merced a la existencia en manos de un tercero de un derecho subjetivo - señaladamente un derecho real- sobre la cosa, cuando dicho ius in re aliena se extingue, la propiedad reabsorbe ${ }^{114}$ aquella o aquellas facultades que hasta entonces

explica- de su propio concepto, estructura y contenido, mientras que los atributos son una exteriorización de aquel concepto, aludiendo a la naturaleza de los poderes o facultades atribuidos al propietario por el ordenamiento. Cfr. José Luis DE LOS Mozos, El derecho de propiedad: crisis y retorno a la tradición jurídica, op. cit., pp. 239 y ss.

${ }^{110}$ La elasticidad es una cualidad mecánica que ostentan todos los cuerpos de modificar su forma no bien se les aplique una fuerza adecuada y de recuperar la forma primitiva cuando se suspende la acción de la fuerza actuante. Eso sí, la elasticidad tiene un límite: si se sobrepasa el mismo, el cuerpo experimenta una deformación permanente o se rompe. Existen determinados cuerpos en que tal propiedad se percibe con facilidad, caso de una liga o de la hoja de un cuchillo. En otros, por el contrario, la elasticidad se manifiesta escasamente, lo que sucede, por ejemplo, con el vidrio o la porcelana.

${ }_{111}$ Cfr. el fundamento jurídico tercero de la RDGRN de 28 de mayo de 2001 [RJ 2001/4809]. Según él «habida cuenta de la elasticidad y carácter abstracto del dominio, cabe constituir un derecho real, como el de hipoteca, que confiere a su titular el "ius disponendi" sobre una cosa ajena, la perteneciente al deudor, sobre la que se constituye la garantía, para el caso de incumplimiento de la obligación asegurada». En idénticos términos, véanse el fundamento jurídico segundo de la RDGRN de 24 de marzo de 2003 [RJ 2003/3957], el fundamento jurídico segundo de la RDGRN de 13 de febrero de 2004 [RJ 2004/2125], el fundamento jurídico tercero de la RDGRN de 29 de diciembre de 2005 [RJ 2006/744] o el fundamento jurídico cuarto de la RDGRN de 28 de noviembre de 2012 [JUR 2012/396124].

${ }_{112}$ Voz «elasticidad», en Diccionario de la Real Academia Española de la Lengua, t. I, 22. ${ }^{a}$ ed., Madrid, Espasa-Calpe, 2001, p. 869. Puede consultarse también en bttp://www.rae.es.

${ }_{113}$ Voz «plástico», en Diccionario de la Real Academia Española de la Lengua, op. cit., t. II, p. 1781.

${ }_{114}$ Véase al respecto el fundamento jurídico tercero de las SSTS de 6 de noviembre de 1992 [RJ 1992/9223] o de 24 de octubre de 2005 [RJ 2005/8285]. 
correspondían jurídicamente a otro titular, esto es, dichas facultades acrecen entonces a la propiedad ${ }^{115}$. Con el adjetivo elástico se evidencia, en definitiva, que el contenido del dominio puede aumentar y decrecer ipso facto, maquinalmente, en cuanto cesa o acaba un derecho real limitado y en cuanto se crea uno nuevo ${ }^{116}$. Una variabilidad de su contenido ${ }^{117}$ que no recorta, en absoluto, la entidad del derecho de propiedad, derecho que, en un caso y en el otro, se estima completo.

El dominio es susceptible de padecer limitaciones o restricciones ${ }^{118}$, pero tan pronto como éstas se disipan, no bien desaparecen las mismas, recupera aquél su nota de generalidad ${ }^{119}$, su canónica integridad. Una generalidad que supone que el dominio engloba en su seno, si no sufre una concreta limitación - y dentro siempre de sus habituales límites o confines-, el total de facultades, aplicaciones y posibilidades que la ley autoriza a tener sobre la cosa (id est, todas las no vetadas por la norma: las actuales y las que puedan surgir en lo venidero, sin necesidad de definirlas o delinearlas ${ }^{120}$ ). Por ello, y como feliz resultado de esa generalidad, se proclama sin ambages la presunción de libertad del dominio, que

115 Cfr. José Antonio Álvarez-CaperochipI, Curso de derechos reales, t. I, 1. ${ }^{a}$ ed., Madrid, Civitas, 1986, p. 39.

${ }^{116}$ El dominio tiene la aptitud de «ensancharse o de reducirse hasta el mínimum — según lo retrata Puig Peña—, de modo tal que el poder del dueño puede llegar a ser poco menos que la nada, sin que, no obstante, esa reducción llegue a destruir totalmente el vínculo de pertenencia que sujeta la cosa a la persona». Cfr. Federico Puig PeÑa, Tratado de Derecho civil español, op. cit., p. 58.

117 «Elasticidad o diferente amplitud de las facultades de uso, disfrute y disposición (que) puede revestir el dominio», como reflejan el considerando tercero de la STS de 22 de enero de 1953 [RJ 1953/258], el considerando quinto de la STS de 10 de diciembre de 1962 [RJ 1962/5060] o el fundamento jurídico sexto de la STSJ de Extremadura de 22 de diciembre de 1999 [JT 1999/1860].

${ }^{118}$ Que son una presión externa al mismo. Cfr. Emilio PÉREz PÉREz, La propiedad inmobiliaria, sus formas y su inscripción registral (propiedad agraria, forestal, de las aguas, de las minas, urbanística, horizontal y de los complejos inmobiliarios privados), 1. ${ }^{a}$ ed., Barcelona, Bosch, noviembre de 2001, p. 58.

${ }^{119}$ La propiedad alcanza virtualmente - como se ha expuesto con anterioridad-a todas las utilidades que el propietario no puede obtener de la cosa en un momento dado, atribuyéndoselas cuando se manifiesten o cuando desaparezcan las restricciones fijadas por las normas legales o por la presencia de derechos a favor de terceros. Por ejemplo, nos ilustra López Fernández, si una carretera varía su trazado, las limitaciones establecidas por la legislación sectorial en relación con el uso de las franjas laterales por los propietarios de los terrenos colindantes también desaparecen. Cfr. Luis Miguel López FERnÁndEZ, Manual de Derecho civil. Derechos reales, coordinado por Rodrigo BERCOVITZ RodríGUEz-Cano, 3. ${ }^{a}$ ed., Madrid, Bercal, 2012, p. 137. Véase igualmente Xavier O'Callaghan Muñoz, Compendio de Derecho civil, op. cit., p. 49.

${ }^{120}$ Cfr. José Luis Lacruz Berdejo, Elementos de Derecho civil, op. cit., $\ 21$, núm. 104, p. 239. 
lo contempla ayuno de cargas y gravámenes (véase el fundamento jurídico segundo de la STS de 14 de octubre de $1996^{121}$ ); presunción que, si bien no se encuentra formulada específicamente en ningún precepto del Código Civil, sí que se infiere de la lectura de varios de sus artículos (350, 358, 540 , etc.). Esto conlleva que, en tanto el dominio se presume libre de cargas y gravámenes, el derecho limitado, que es al paso limitativo de la propiedad, queda como excepción a la regla general y ha de ser probado. «En la gestación del concepto moderno de propiedad como dominium plenum —recapitula De los Mozos_ ${ }^{122}$ y en la lucha por la eliminación de vinculaciones y amortizaciones de origen feudal, este principio se expresaba como el de la libertad de los fundos, concepto que todavía recoge la Ley Hipotecaria (arts. 38 y 225) y su Reglamento (art. 51.7.a)».

Se diferencian, no obstante, en la esfera conceptual la generalidad y la elasticidad ${ }^{123}$. El que el señorío del dominus sea general implica que abarca todas las facultades. El que sea elástico indica un paso más en la misma línea; es decir, la vis atractiva (o perenne capacidad de atracción) que el dominio ejerce sobre tales facultades desglosadas ${ }^{124}$ o detraídas ${ }^{125}$ hace que ellas no puedan permanecer nunca solas, sin titular, porque si así fuera, al no constituir ya el contenido de un gravamen que comprime la propiedad $^{126}$, se hallarían disueltas de nuevo en el acervo dominical. Cualquier facultad representativa de un ius in re aliena que deviene nullius o se desvanece, retorna indefectiblemente al seno de la propiedad gracias a la fuerza o vigor expansivos de esta última ${ }^{127}$. Y hete aquí una cualidad de la que

${ }^{121}$ Establece literalmente: «Las limitaciones, como las prohibiciones de disponer, no se presumen, es necesario acreditar su efectiva concurrencia y, de ser así, han de ser objeto de interpretación restrictiva» [RJ 1996/7107].

${ }^{122}$ José Luis DE LOS Mozos, El derecho de propiedad: crisis y retorno a la tradición jurídica, op. cit., p. 240.

${ }_{123}$ Cfr. José Luis Lacruz Berdejo, Elementos de Derecho civil, op. cit., $\$ 21$, núm. 104, p. 240.

${ }^{124}$ Véase José Á. Torres Lana, Código Civil. Doctrina y jurisprudencia, op. cit., p. 68.

125 Cfr. Vicente L. Montés Penadés, Comentarios al Código Civil, op. cit., p. 163. A tenor del fundamento jurídico tercero de la STSJ de Cataluña de 29 de junio de 2007 [JT 2007/1045], «la "elasticidad del derecho de dominio" [...] entiende comprendidos en dicho derecho todas y cada una de las facultades que pueden ejercitarse sobre el bien, en tanto en cuanto no se desgajen de dicho derecho, mediante la constitución de un derecho real sobre cosa ajena». Véase también el fundamento jurídico cuarto de la STS de 19 de mayo de 2006 [RJ 2006/3047].

${ }^{126}$ Cfr. sobre el particular Lodovico BARAssi, La proprietà nel nuovo Codice Civile, op. cit., $\$ 1$, núm. 3, p. 8. Véase también José Antonio ÁlvareZ-CaPEROCHIPI, Curso de derechos reales, op. cit., p. 39.

${ }^{127}$ El fundamento jurídico quinto de la STS de 13 de diciembre de 2010 [RJ 2011/140] 
están desprovistos los derechos reales limitados, los cuales - y bien que lo ve Lacruz- ${ }^{128}$ no atraerían a su terreno ni comunicarían a su titular otros derechos de igual rango sobre la misma cosa, pues éstos no forman parte de su contenido. Por eso, quedando nullius por abandono del dueño una cosa objeto de usufructo, tal derecho no atrae a la nuda propiedad abandonada incorporándola a él, mientras que, fenecido el usufructo, las facultades correspondientes regresan a poder del propietario, coligiéndose que se han incorporado de manera automática a la mera propiedad para componer el armazón o andamiaje jurídico del pleno dominio.

\section{BIBLIOGRAFÍA}

Alas Argüelles, L., Derecho civil, Madrid, Reus, 1929.

Albaladejo García, M., Derecho civil, t. III, 11. a ed. revisada por E. Cordero Lobato, Madrid, Edisofer, 2010.

Alonso Martínez, M., «Estudios sobre el derecho de propiedad», en C. Rogel y

C. VAtTier (coords.), Manuel Alonso Martínez. Vida y obra, Madrid, Tecnos-

Caja de Ahorros Municipal de Burgos, 1991, pp. 861-1037.

Álvarez-Caperochipi, J. A., Curso de derechos reales, t. I, 1. a ed., Madrid, Civitas, 1986.

Aubry, C., et Rau, C., Cours de droit civil français d'après la méthode de Zachariae,

t. II, 4. ${ }^{a}$ ed. revisada y puesta al día, Paris, Cosse, Marchal \& Cie, Imprimeurs-

Éditeurs, 1869.

Barassi, L., La proprietà nel nuovo Codice Civile, 2. ed., Milano, Giuffrè, 1943.

Bartolo, Opera omnia, t. V, Venezia, 1615.

Bercovitz Álvarez, G., Comentarios al Código Civil, coordinado por R. Bercovitz

Rodríguez-Cano, 3. a ed., Cizur Menor (Navarra), Aranzadi-Thomson Reuters, 2009.

Bercovitz Rodríguez-Cano, R., Qué es la propiedad, Barcelona, La Gaya Ciencia, 1977.

Blasco Gascó, F. de P., y Cecchini Rosell, X., Comentarios al Código Civil, coordinado por J. Rams Albesa, t. III, Barcelona, Bosch, 2001.

Bonfante, P., Corso di diritto romano, vol. II, parte I, ristampa corretta della 1. a edizione a cura di G. Bonfante e di G. CRIfò con l'aggiunta degli indici delle fonti, Milano, Giuffrè, 1966.

remite a la «eventualidad expansiva derivada del principio de la elasticidad — fuerza centrípeta del dominio- $\gg$.

${ }^{128}$ José Luis Lacruz Berdejo, Elementos de Derecho civil, op. cit., $\$ 21$, núm. 104, p. 240. 
Borrell i Soler, A. M., El dominio según el Código Civil español, Barcelona, Bosch, 1948.

BRugi, B., Della proprietà, vol. I, ristampa della 2. ${ }^{a}$ edizione intieramente rifatta e corredata di indice alfabetico, Napoli-Torino, Eugenio Marghieri-Utet, 1923.

Cabanellas, G., voz «propiedad», en Diccionario de Derecho Usual, t. III, 10. a ed., Buenos Aires, Heliasta, 1976, pp. 406-407.

Carbonnier, J., Droit Civil, vol. II, 1. a ed., Paris, Quadrige-Puf, 2004.

Castán Tobeñas, J., La propiedad y sus problemas actuales, 2. ${ }^{a}$ ed. revisada y ampliada, Madrid, Instituto Editorial Reus, 1963.

- Derecho civil español, común y foral, t. II, vol. I, 14. ${ }^{a}$ ed. revisada y puesta al día por G. García Cantero, Madrid, Reus, 1992.

El Código Civil. Debates parlamentarios (1885-1889), t. I, estudio preliminar de J. L. De los Mozos, edición preparada por R. Herrero Gutiérrez y M. Á. Vallejo Úbeda, Madrid, Servicio de Publicaciones de la Secretaría General del Senado, 1989.

Código Civil alemán y ley de introducción al Código Civil, traducción de A. Lamarca Marqués, Madrid, Marcial Pons, 2008.

De Azcárate, G, Ensayo sobre la bistoria del derecho de propiedad y su estado actual en Europa, t. III, Madrid, Imprenta de la Revista de Legislación, 1883.

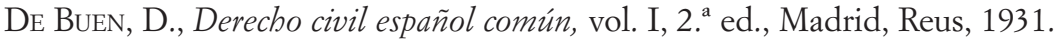

De Diego, F. C., Instituciones de Derecho civil español, Madrid, Imprenta de Juan Pueyo, 1929.

De Los Mozos, J. L., El derecho de propiedad: crisis y retorno a la tradición jurídica, Madrid, Edersa, 1993.

De Pablo Contreras, P. (coord.), Curso de Derecho civil, vol. III, 3. . ed., Madrid, Colex, 2011.

De Page, H., Traité élémentaire de droit civil belge, t. V, avec la collaboration, pour la partie relative aux biens, de R. DEKKERS, nouveau tirage conforme au premier, Bruxelles, Établissements Émile Bruylant, 1952.

De Ruggiero, R., Instituciones de Derecho Civil, vol. I, traducción de la 4. ${ }^{a}$ ed. italiana anotada y concordada con la legislación española por R. SERRANO SÚÑER y J. Santa-Cruz Teijeiro, Madrid, Reus, 1929.

Díez-Picazo, L., Fundamentos del Derecho civil patrimonial, t. III, 5. ed., Cizur Menor (Navarra), Thomson-Civitas, 2008.

- «Propiedad y Constitución», en VVAA, Propiedad y Derecho civil, Madrid, Colegio de Registradores de la Propiedad y Mercantiles de España, 2006, pp. 13-22.

Díez-Picazo, L., y Gullón Ballesteros, A., Sistema de Derecho civil, vol. III, t. I, 8. ${ }^{a}$ ed., Madrid, Tecnos, 2012.

Di Marzo, S., Le basi romanistiche del Codice Civile, Torino, Utet, 1950.

Dusi, B., Istituzioni di diritto civile, vol. I, rivedute ed aggiornate dal M. SARFATTI, 2. ${ }^{\text {a }}$ ed., Torino, Libreria Scientifica Giappichelli, 1945. 
Escribano, T., «La propiedad y el art. 348 del Código Civil español», RDP, año IV, núm. 30, 15 de marzo de 1916, pp. 64-70.

Espín CÁnovas, D., Manual de Derecho civil español, vol. II, 3. ${ }^{a}$ ed. revisada y puesta al día, Madrid, Edersa, 1968.

Farré Alemán, J. M. a , Código Civil comentado y concordado, 1. ${ }^{\text {a }}$ ed., Barcelona, Bosch, enero de 2001.

Femenía López, P. J., Comentarios al Código Civil, dirigido por R. Bercovitz Rodríguez-Cano, t. II, Valencia, Tirant lo Blanch, 2013.

García Goyena, F., Concordancias, motivos y comentarios del Código Civil español, t. I, Madrid, Imprenta de la Sociedad Tipográfico-Editorial, 1852.

Hattenhauer, H., Conceptos fundamentales del Derecho civil. Introducción histórica y dogmática, traducción de G. Hernández, 1. ${ }^{a}$ ed., Barcelona, Ariel, julio de 1987.

HeRnÁNDEZ GIL, A., «La propiedad y su transformación», Obras Completas, t. IV, Madrid, Espasa-Calpe, 1989, pp. 41-74.

Instituciones de Justiniano, edición bilingüe con una nota previa sobre Justiniano y las Institutas por M. Ortolán, traducción de F. Pérez de Anaya y M. Pérez Rivas, Buenos Aires, Heliasta, s.f.

Las Siete Partidas de Alfonso X el Sabio (El Libro del Fuero de las Leyes), introducción y edición dirigida por J. SÁnchez-Arcilla Bernal, Madrid, Reus, 2004.

Lacruz Berdejo, J. L., Elementos de Derecho civil, t. III, vol. I, 3. a ed. revisada y puesta al día por A. Luna Serrano, Madrid, Dykinson, 2008.

Lasarte Álvarez, C., Principios de Derecho civil, t. IV, 10. ${ }^{a}$ ed., Madrid, Marcial Pons, 2010.

Laurent, F., Principes de Droitcivilfrançais, tVI, Paris-Bruxelles, A. Durand\&Pedone Lauriel/Bruylant-Christophe\&Comp., 1871.

Levi, A., Teoria generale del diritto, ristampa anastatica della 2. ${ }^{\text {a }}$ ed., Padova, Cedam, 1967.

López de Tovar, G., Las Siete Partidas, t. III, Salamanca, A. de Portonariis, 1555.

López Fernández, L. M., Manual de Derecho civil. Derechos reales, coordinado por R. Bercovitz Rodríguez-Cano, 3. ${ }^{a}$ ed., Madrid, Bercal, 2012.

LÓPEZ y LóPEz, Á. M., La disciplina constitucional de la propiedad privada, Madrid, Tecnos, 1988.

- «El derecho de propiedad. Una relectio», ADC, t. LI, fasc. IV, octubre-diciembre de 1998, pp. 1637-1691.

- Código Civil comentado, coordinado por P. De Pablo Contreras y R. Valpuesta Fernández, vol. I, 1. a ed., Cizur Menor (Navarra), Civitas-Thomson Reuters, 2011.

Manresa y Navarro, J. M., Comentarios al Código Civil español, t. III, 7. a ed. revisada y puesta al día por J. Calvillo Martínez de Arenaza, Madrid, Reus, 1952.

Martín Pérez, J. A., Comentarios al Código Civil, dirigido por A. Domínguez Luelmo, 1. a ed., Valladolid, Lex Nova, mayo de 2010. 
Messineo, F., Manual de Derecho civil y comercial, traducción de S. Sentis Melendo, t. III, Buenos Aires, Ediciones Jurídicas Europa-América, 1971.

Miñarro Montoya, R., «La propiedad desde el punto de vista del Derecho civil: limitaciones del derecho de propiedad», en VVAA, Propiedad y Derecho civil, Madrid, Colegio de Registradores de la Propiedad y Mercantiles de España, 2006, pp. 231-261.

Montés Penadés, V. L., La propiedad privada en el sistema del Derecho civil contemporáneo (un estudio evolutivo desde el Código Civil hasta la Constitución de 1978), 1. 'ed., Madrid, Civitas, 1980.

- Comentarios al Código Civil, dirigido por M. Albaladejo, t. V, vol. I, 2. ${ }^{a}$ ed. totalmente reelaborada y adaptada a la nueva legislación, Madrid, Edersa, 1990.

- Comentario del Código Civil, dirigido por C. Paz-Ares Rodríguez, R. Bercovitz, L. Díez-Picazo Ponce de León y P. Salvador Coderch, t. I, Madrid, Ministerio de Justicia, 1991.

O’Callaghan Muñoz, X., Código Civil comentado y con jurisprudencia, 5. a ed., Madrid, La Ley, septiembre de 2006.

- Compendio de Derecho civil, t. III, 1. ${ }^{a}$ ed., Madrid, Editorial Universitaria Ramón Areces, septiembre de 2012.

Pantaleón Prieto, Á. F., «La libertad del dominio», en VVAA, Propiedad y Derecho civil, Madrid, Colegio de Registradores de la Propiedad y Mercantiles de España, 2006, pp. 61-77.

Peña Bernaldo de Quirós, M., Derechos reales. Derecho hipotecario, t. I, 3. a ed., Madrid, Centro de Estudios Registrales, 1999.

PÉREZ PÉREZ, E., La propiedad inmobiliaria, sus formas y su inscripción registral (propiedad agraria, forestal, de las aguas, de las minas, urbanística, horizontal $y$ de los complejos inmobiliarios privados), 1. ' ed., Barcelona, Bosch, noviembre de 2001.

Piccinelli, F., Studi e ricerche intorno alla definizione dominium est ius utendi et abutendi re sua, quatenus iuris ratio patitur (rist. anast. 1886), con una nota di lettura di L. CAPogrossi Colognesi, Napoli, Jovene (Collana Antiqua), 1980.

Planiol, M., y RiPeRT, G., Tratado práctico de Derecho civil francés, traducción española de M. Díaz Cruz, t. III, con el concurso de M. Picard, La Habana, Juan Buxó, 1930.

Pothier, R. J., Traité du droit de domaine, nouvelle édition, Paris, Letellier, 1807.

Puig Brutau, J., Fundamentos de Derecho civil, t. III, vol. I, 4. a ed., Barcelona, Bosch, 1994.

Puig PeÑa, F., Tratado de Derecho civil español, t. III, vol. I, Madrid, Edersa, s.f.

Quaranta, A., Commentario teorico-pratico al Codice Civile, libro III, Della proprietà. Beni e proprietà in generale (art. 810-870), diretto da V. DE MARTino, 1. ${ }^{\text {e }}$ d., Novara-Roma, Edizioni Pem, 1970. 
Rescigno, P., voz «proprietà (diritto privato)», Enciclopedia del Diritto, vol. XXXVII, Milano, Giuffrè, 1988, pp. 254-297.

Roca SAStRe, R. M. ${ }^{a}$, «La concepción del usufructo como pars dominii y sus reflejos en la legislación del impuesto de derechos reales», RGLJ, año LXXXVII, núm. 6, segunda época, tomo IV (172 de la colección), diciembre de 1942, pp. $575-587$.

Rodríguez-Zapata Pérez, J., «La propiedad privada: de cenicienta a derecho fundamental», RGLJ, año CXLVIII, núm. 3, julio-septiembre de 2001, pp. 601-620.

Sánchez Román, F., Estudios de Derecho civil, t. III, Madrid, Est. Tip. Sucesores de Rivadeneyra, 1900.

Santamaría, J., Comentarios al Código Civil, t. I, Madrid, Edersa, 1958.

Scaevola, Q. M., Código Civil comentado y concordado extensamente, t. VI, totalmente revisado y puesto al día por F. Ortega LorCA, 5. ${ }^{\text {a }}$ ed., Madrid, Instituto Editorial Reus, 1949.

Serra Rodríguez, A., Derecho civil III, coordinado por A. Serra Rodríguez y J. Ramón de Verda y Beamonte, Valencia, Tirant lo Blanch, 2010.

Serrano Alonso, E., y Serrano Gómez, E., Manual de derechos reales, 2. ${ }^{\text {a }}$ ed. revisada y puesta al día, Madrid, Edisofer, 2008.

Sierra Gil de la Cuesta, I. (coord.), Comentario del Código Civil, t. III, Barcelona, Bosch, 2006.

S. S. Juan XXIII, Encíclica Mater et Magistra, edición publicada por la Oficina de Coordinación y Programación Económica utilizando la traducción castellana hecha por la Tipografía Políglota Vaticana, Madrid, 1961.

Torres Lana, J. Á., Código Civil. Doctrina y jurisprudencia, dirigido por J. L. Albá-

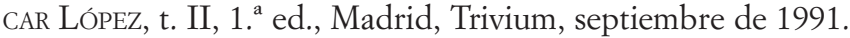

Valverde y Valverde, C., Tratado de Derecho civil español, t. II, 3. a ed. corregida y aumentada, Valladolid, Talleres Tipográficos Cuesta, 1925.

Vattier, C. S., «La elasticidad del derecho de propiedad en los planes de mejora ejecutados mediante arrendamiento forzoso en el Derecho agrario español», RCDI, año LII, núm. 515, julio-agosto de 1976, pp. 833-857.

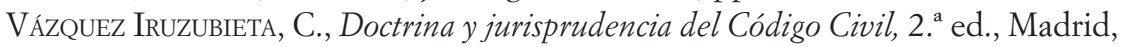
Edersa, 1988.

WinsDcheID, B., Diritto delle pandette, traduzione dei professori C. Fadda e P. Emilio Bensa, con note e riferimenti al Diritto civile italiano, nuova ristampa stereotipa, vol. I, Torino, Utet, 1925.

WIRTH, K., Beiträge zur Systematik des römischen Civilrechts insbesondere binsichtlich obligatorischer und dinglicher Rechte, Erlangen, Verlag von A. Deichert, 1856.

Wolff, M., Derecho de cosas, en L. Enneccerus, T. Kipp y M. WolfF, Tratado de Derecho civil, t. III, décima revisión por M. WOLFF y L. RAISER, traducción española con anotaciones de B. Pérez González y J. Alguer, vol. I, 3. a ed. al cuidado de J. Puig Brutau, Barcelona, Bosch, 1971. 


\section{SENTENCIAS Y RESOLUCIONES CITADAS}

STS de 22 de enero de 1914, Jurisprudencia Civil, t. 129, enero-mayo de 1914, núm. 35.

STS de 21 de noviembre de 1929, Jurisprudencia Civil, t. 191, noviembre-diciembre de 1929, núm. 63.

STS de 17 de noviembre de 1930 [RJ 1930/1265].

STS de 20 de octubre de 1941 [RJ 1941/1087].

STS de 3 de diciembre de 1946 [RJ 1946/1299].

STS de 23 de diciembre de 1946 [RJ 1946/1413].

STS de 22 de enero de 1953 [RJ 1953/258].

STS de 12 de junio de 1958 [RJ 1958/2763].

STS de 10 de diciembre de 1962 [RJ 1962/5060].

STS de 2 de octubre de 1975 [RJ 1975/3410].

STS de 21 de febrero de 1981 [RJ 1981/1147].

STC de 2 de diciembre de 1983 [RTC 1983/111].

STC de 26 de marzo de 1987 [RTC 1987/37].

STS de 27 de junio de 1991 [RJ 1991/9821].

STS de 6 de noviembre de 1992 [RJ 1992/9223].

STS de 20 de mayo de 1993 [RJ 1993/3807].

STS de 1 de marzo de 1994 [RJ 1994/1633].

STC de 17 de marzo de 1994 [RTC 1994/89].

STS de 14 de octubre de 1996 [RJ 1996/7107].

STSJ de Extremadura de 22 de diciembre de 1999 [JT 1999/1860].

RDGRN de 28 de mayo de 2001 [RJ 2001/4809].

RDGRN de 24 de marzo de 2003 [RJ 2003/3957].

RDGRN de 13 de febrero de 2004 [RJ 2004/2125].

STS de 7 de octubre de 2005 [RJ 2005/6919].

STS de 24 de octubre de 2005 [RJ 2005/8285].

RDGRN de 29 de diciembre de 2005 [RJ 2006/744].

STS de 19 de mayo de 2006 [RJ 2006/3047].

STSJ de Cataluña de 29 de junio de 2007 [JT 2007/1045].

STS de 13 de diciembre de 2010 [RJ 2011/140].

RDGRN de 28 de noviembre de 2012 [JUR 2012/396124]. 